\title{
Money Doctors
}

\section{Citation}

Gennaioli, Nicola, Andrei Shleifer, Robert Vishny. 2015. Money doctors. The Journal of Finance 70: 91-114.

\section{Published Version}

doi:10.1111/jofi.12188

\section{Permanent link}

http://nrs.harvard.edu/urn-3:HUL.InstRepos:12965657

\section{Terms of Use}

This article was downloaded from Harvard University's DASH repository, and is made available under the terms and conditions applicable to Open Access Policy Articles, as set forth at http:// nrs.harvard.edu/urn-3:HUL.InstRepos:dash.current.terms-of-use\#OAP

\section{Share Your Story}

The Harvard community has made this article openly available.

Please share how this access benefits you. Submit a story.

Accessibility 


\title{
Money Doctors
}

\section{NICOLA GENNAIOLI, ANDREI SHLEIFER, and ROBERT VISHNY*}

\begin{abstract}
We present a new model of investors delegating portfolio management to professionals based on trust. Trust in the manager reduces an investor's perception of the riskiness of a given investment, and allows managers to charge fees. Money managers compete for investor funds by setting fees, but because of trust fees do not fall to costs. In equilibrium, fees are higher for assets with higher expected return, managers on average underperform the market net of fees, but investors nevertheless prefer to hire managers to investing on their own. When investors hold biased expectations, trust causes managers to pander to investor beliefs.
\end{abstract}

\footnotetext{
* The authors are from Universita Bocconi and IGIER, Harvard University, and University of Chicago, respectively. We are grateful to Charles Angelucci, Nicholas Barberis, John Campbell, Roman Inderst, Sendhil Mullainathan, Lubos Pastor, Raghuram Rajan, Jonathan Reuter, Joshua Schwartzstein, Charles-Henri Weymuller, Luigi Zingales, Yanos Zylberberg, and especially a referee for extremely helpful comments.

Disclosure: Shleifer was a co-founder of LSV Asset Management, a money management firm, but is no longer a shareholder in the firm. Shleifer's wife is a partner in a hedge fund, Bracebridge Capital. Vishny was a co-founder of LSV Asset Management. He retains an ownership interest.
} 
It has been known since Jensen (1968) that professional money managers on average underperform passive investment strategies net of fees. Gruber (1996) estimates average mutual fund underperformance of 65 basis points per year; French (2008) updates this to 67 basis points per year. But such poor performance of mutual funds is only the tip of the iceberg. Many investors pay substantial fees to brokers and investment advisors, who then direct them toward the mutual funds that underperform (Bergstresser, Chalmers, and Tufano (2009), Chalmers and Reuter (2012), Del Guercio, Reuter, and Tkac (2010), Hackethal, Haliassos, and Jappelli (2012)). Once all fees are taken into account, some studies find $2 \%$ investor underperformance relative to indexation. ${ }^{1}$ This evidence is difficult to reconcile with the view that investors are comfortable investing in a low-fee index fund on their own, but nonetheless seek active managers to improve performance.

In fact, performance seems to be only part of what money managers seek to deliver. Many leading investment managers and nearly all registered investment advisors advertise their services based not on past performance but instead on trust, experience, and dependability (Mullainathan, Schwartzstein, and Shleifer (2008)). Some studies of mutual funds note that investors hiring advisors must be obtaining some benefits apart from portfolio returns (Hortacsu and Syverson (2004)). We take this perspective seriously and propose an alternative view of money management that is based on the idea that investors do not know much about finance, are too nervous or anxious to make risky investments on their own, and hence hire money managers and advisors to help them invest. Managers may have knowledge of how to diversify or even ability to earn alpha, but in addition they provide investors peace of mind. We focus on individual investors, but similar issues apply to institutional investors (Lakonishok, Shleifer, and Vishny (1992)).

Critically, we do not think of trust as deriving from past performance. Rather, trust describes confidence in the manager that is based on personal relationships, familiarity, persuasive advertising, connections to friends and colleagues, communication, and schmoozing. There are (at least) two distinct aspects of such trust. The first, stressed by Guiso, Sapienza, and Zingales (2004, 2008) and Georgarakos and Inderst (2011), sees trust as security from expropriation or theft. The 
other aspect, emphasized here, has to do with reducing investor anxiety about taking risk. With U.S. securities laws, most investors in mutual funds probably do not fear that their money will be stolen; rather, they want to be "in good hands."

We think of money doctors as families of mutual funds, registered investment advisors, financial planners, brokers, funds of funds, bank trust departments, and others who give investors confidence to take risks. Some investors surely do not need advice and invest on their own, although Calvet, Campbell, and Sodini (2007) suggest that many such investors do not diversify properly. But many other investors, ranging from relatively poor employees asked to allocate their defined contribution pension plans (Chalmers and Reuter (2012)) to millionaires hiring "wealth managers" rely on experts to help them invest in risky assets and thus earn higher expected returns. On their own, these investors would not have the time, the expertise, or the confidence to buy risky assets, and just leave their money in the bank.

In our view, financial advice is a service, similar to medicine. We believe, contrary to what is presumed in the standard finance model, that many investors have very little idea of how to invest, just as patients have a very limited idea of how to be treated. And just as doctors guide patients toward treatment, and are trusted by patients even when providing routine advice identical to that of other doctors, in our model money doctors help investors make risky investments and are trusted to do so even when their advice is costly, generic, and occasionally self-serving. And just as many patients trust their doctor, and do not want to go to a random doctor even if equally qualified, investors trust their financial advisors and managers.

We present a model of the money management industry in which the allocation of assets to managers is mediated by trust. We model trust as reducing the utility cost for the investor of taking risk, much as if it reduces the investor's subjective perception of the risk of investments. Critically, managers differ in how much different investors trust them - an investor who trusts a particular manager perceives returns on risky investments delivered by this manager as less uncertain than 
those delivered by a less trusted manager. We discuss alternative ways of modeling investor trust, but argue that ours is both natural and consistent with the data.

In particular, an investor would prefer to make a given investment with the manager he trusts most, enabling that manager to charge the investor a higher fee and still keep him. Even if managers compete on fees, these fees do not fall to costs, and substantial market segmentation remains. In fact, in our model fees are proportional to expected returns, with higher fees in asset classes with higher risk and return. Net of fees, investors consistently underperform the market, but experience less anxiety and earn higher expected returns than they would by investing on their own. A very simple formulation based on trust thus delivers some of the basic facts about money management that the standard approach finds puzzling. ${ }^{2}$

In this framework, under rational expectations managers charge high fees but at the same time enable investors to take more risk. Investors are better off, and there are no distortions in investment allocation between asset classes. Interesting issues arise, however, when investors do not hold rational expectations and perhaps want to invest in hot asset classes or new products they believe will earn higher returns, such as internet stocks in the late 1990s. Empirical evidence supports the role of investor extrapolation in financial markets (e.g., Lakonishok, Shleifer, and Vishny (1994), Hurd and Rohwedder (2012), Greenwood and Shleifer (2014)). Do trusted money managers correct investors' errors, or pander to their beliefs? In our model, managers have a strong incentive to pander, precisely because pandering gets investors who trust the manager to invest more, and at higher fees. Trust-mediated money management does not work to correct investor biases. In equilibrium, money managers let investors chase returns by proliferating product offerings.

We also consider the dynamics of professional money management, including the possibility that over time better performers attract more funds (Chevalier and Ellison (1999)). In this context, we ask whether professional managers have an incentive to pursue contrarian strategies and try to beat the market. We present a standard dynamic model of career concerns in which 
managers have the ability to earn alpha, and are rewarded for doing so by attracting fund flows, but we augment this model with trust. We find that career concern incentives are significantly moderated by trust, because a manager must trade off the benefits of attracting future funds due to superior performance against the cost of discouraging trusting clients who want to invest in hot sectors such as internet stocks. Current profits from pandering may dominate reputational incentives when manager-specific trust is important because such trust i) allows managers to charge high fees in hot assets, and ii) reduces investor mobility to better-performing managers. As an example, value managers during the internet bubble had a strong incentive to switch to "growth-atthe-right-price" and pander to their investors' desire to hold technology stocks, even when these managers understood that technology stocks were overpriced. Even with performance pressures, when trust is important there are strong incentives to pander to client biases and only a weak incentive to bet against market mispricing. This result has implications for the effectiveness of professional arbitrage, market efficiency, and financial stability.

Our paper is related to several areas of research. Since Putnam (1993), economists have studied the role of trust in shaping economic and political outcomes (e.g., Knack and Keefer (1997), La Porta et al. (1997)). In finance, this research was pursued most productively by Guiso, Sapienza, and Zingales $(2004,2008)$, who show that trust in institutions encourages individuals to participate in financial markets, whether by opening checking accounts, seeking credit, or investing in stocks. Taking a related perspective, we stress the anxiety-reducing aspects of manager-specific trust rather than trust in the broader system.

In addition to voluminous research documenting poor performance of equity mutual funds, some papers document net-of-fees underperformance by bond mutual funds (Blake, Elton, and Gruber (1993), Bogle (1998)) and hedge funds (Asness, Krail, and Liew (2001)). An important finding of this work is that fees are higher in riskier (higher-beta) asset classes, so that managers appear to be paid for taking market risk. One would not expect this feature in a standard model of 
delegated management in which only superior performance - alpha - should be rewarded. Trust, however, naturally accounts for this phenomenon.

Following Campbell (2006), financial economists have considered the nature and consequences of investment advice. Some of these studies suggest that investment advice is so poor that managers chosen by the advisors underperform the market even before fees. Gil-Bazo and Ruiz-Verdú (2009) find that the highest fees are charged by managers with the worst performance. This finding is consistent with a central prediction of our model that managers cater to investor biases. An audit study by Mullainathan, Noeth, and Schoar (2012) similarly finds that advisors direct investors toward hot sector funds, pandering to their extrapolative tendencies. In contrast, unbiased investment advice is ignored (Bhattacharya et al. (2012)).

Our study of incentives in money management follows, but takes a different approach from, traditional work on performance incentives (e.g., Chevalier and Ellison (1997, 1999)). Two recent papers that address some of the issues we focus on here, but in the traditional context in which reputations are shaped entirely by performance, are Guerrieri and Kondor (2012) and Kaniel and Kondor (2013). Closer to our work are the papers by Inderst and Ottaviani (2009, 2012a, 2012b), who focus on distorted incentives to sell financial products arising both from the difficulties of incentivizing salesmen to sell appropriate products and from actual kickbacks. Hackethal, Inderst, and Meyer (2012) find empirically that investors who rely more heavily on advice have a higher volume of security transactions and are more likely to invest in products that salesmen are incentivized to sell. Our focus is on the incentives of the money management organization itself when its clients' choices are mediated by trust.

Several papers ask whether agents have incentives to conform or be contrarian. Outside of finance, Prendergast (1993), Morris (2001), Canes-Wrone, Herron, and Schotts (2001), and Mullainathan and Shleifer (2005) present models in which agents pander to principals. In finance, a large literature starting with Scharfstein and Stein (1990) and Bikhchandani, Hirshleifer, and Welch 
(1992) describes the incentives for herding and conformism. The novel feature of our model is its focus on trust as distinct from performance in shaping incentives.

In Section I we present our basic model of trust and delegation. In Section II, we solve the model and show that even the simplest specification delivers some of the basic facts about the industry. In Section III we extend the model to the case of multiple financial products. In Section IV we examine the incentives of managers to pander to investors with biased expectations both in a static context and in a dynamic model in which managers can earn alpha if they pursue returnmaximizing strategies. Section V concludes with a discussion of some implications of our model.

\section{The Basic Setup}

There are two periods $t=0,1$ and a mass one of investors who enjoy consumption at $t=1$ according to a utility function that we specify below. At $t=0$, each investor is endowed with one unit of wealth. There are two assets. The first asset is riskless (Treasuries or bank accounts), and yields $R_{f}>1$ at $t=1$. The second asset is risky (e.g., equities or bonds); it yields an expected excess return $R$ over the riskless asset, and has a variance of $\sigma$. The risky asset is in perfectly elastic supply and riskless borrowing is unrestricted. One can view this setup as a small open economy where the supply of assets adjusts to demand. We are thus looking at the portfolio choice problem taking asset prices and expected returns as given.

At $t=0$, each investor $i$ invests shares $x_{i}$ and $1-x_{i}$ of his wealth in the risky and riskless asset, respectively. The investor can perfectly access the riskless asset but not the risky asset. The reason is that the risky asset requires management (e.g., to create a diversified portfolio) and the investor lacks the necessary expertise or time. Without expert money managers, the investor cannot take risk. This implies, in particular, that even an index fund investment requires a manager or an advisor; the investor does not want to make the investment on his own. ${ }^{3}$ The assumption of no homemade risk-taking might seem too strong, but it enables us to show our results most clearly. It also sharpens the analogy to medicine, in which patients seek medical advice for all but the simplest 
and safest treatments. It is not critical to our findings that investors do not take risk on their own, but rather that they take more risk with a manager. Likewise, our results hold if some expert investors are not anxious about making risky investments on their own and do so without investment advice. In this case, managers compete for the remaining investors who are anxious and do require investment advice.

To implement the risky investment $x_{i}>0$ the investor hires one of two managers, $A$ or $B$ (for simplicity he cannot hire both). Delegation requires investor trust. We introduce trust in the standard model of portfolio choice where investors have mean-variance preferences. We first describe our setup formally and then discuss it. We capture investor $i$ 's lack of trust toward manager $j=A, B$ by a parameter $a_{i, j} \geq 1$ that multiplies the investor's baseline risk aversion. That is, the cost to investor $i$ of bearing one unit of risk with manager $j$ is given by $a_{i, j} / 2$. This idea is formalized by assuming that each investor $i$ has the quadratic utility function

$$
u_{i, j}(c)=\mathbb{E}(c)-\frac{a_{i, j}}{2} \operatorname{Var}(c)
$$

The investor's baseline risk aversion is normalized to $1 / 2$. His effective risk aversion in delegating to manager $j$ is equal to $a_{i, j} / 2 \geq 1 / 2$. We can view $a_{i, j}$ as the anxiety suffered by investor $i$ for bearing risk with manager $j$. In this setup, the assumption of no risk-taking without advice means that investor $i$ is infinitely anxious when investing on his own. Investor $i$ suffers less anxiety if he delegates his risky investment to his most trusted manager.

Half of the investors trust $A$ more than $B$, the other half trust $B$ more than $A$. The anxiety suffered by investor $i$ for bearing risk with his most trusted manager is equal to $a$. The anxiety suffered by the same investor for bearing risk with his least trusted manager is equal to $a / \tau_{i}$, where $\tau_{i} \in[0,1] . \quad$ That is, an " $A$-trusting" investor $i$ suffers anxiety $a_{i, A}=a$ with manager $A$ and $a_{i, B}=a / \tau_{i}$ with manager $B$; a " $B$-trusting" investor $i$ suffers anxiety $a_{i, A}=a / \tau_{i}$ with manager $A$ and $a_{i, B}=a$ with manager $B$. Parameter $\tau_{i}$ captures the relative trust of investor $i$ in his less trusted manager, measuring the extent to which the two managers are substitutes from the 
standpoint of investor $i$. An investor with $\tau_{i}=1$ sees the two managers as perfect substitutes. An investor with $\tau_{i}<1$ views his less trusted manager as an imperfect substitute for the more trusted one. When $\tau_{i}=0$, the investor suffers infinite anxiety when investing with his less trusted manager, just as he would when taking risk on his own.

Investors vary in how much they trust one manager over the other. In particular, in the population of investors $\tau_{i}$ is uniformly distributed on $[1-\theta, 1]$ for both $A$ - and $B$-trusting investors. Parameter $\theta \in[0,1]$ captures the dispersion of trust in the population: the higher is $\theta$, the more investors trust one manager more than the other. At $\theta=0$, investors are homogeneous in the sense that they trust the two managers equally - this is the benchmark case of Bertrand competition. With dispersion in trust levels, managers have some market power with respect to investors who trust them more, and optimally charge positive fees even in a competitive market. Trust is permanent and does not depend on or change with returns.

In sum, in our model attitudes toward risk are shaped by four parameters. The first is baseline risk aversion, normalized to $1 / 2$, which captures an investor's preference over "neutral" bets (as elicited using lotteries in a lab experiment). The second parameter is the investor's anxiety $a_{i, i}=\infty$ of taking financial risk on his own, reflecting the investor's lack of confidence in his own financial expertise, which may arise from his uncertainty or ambiguity over the distribution of returns. The third parameter $a<\infty$ captures the reduction in anxiety experienced by the investor when he takes financial risk with his most trusted manager. This captures the comfort created by the trusted manager's expertise, reflected, for instance, by a tighter perceived distribution of asset returns. The last parameter is the dispersion $\theta$ in the trust that investors have in different managers. A higher $\theta$ increases the anxiety experienced by the average investor when switching from his more to his less trusted manager. ${ }^{4}$

Two final comments are in order. First, this specification is very different from the standard approach to the delegation problem, in which investors seek advice to achieve a better risk-return 
combination rather than to gain some comfort or confidence in taking risk. Second, we model trust in a manager as a parameter capturing the extra risk the investor is willing to bear to earn an extra unit of return. This specification most accurately captures the idea that we seek to formalize, namely, that trust in managerial expertise tightens the distribution of returns perceived by the investor, making it less costly for him to take risk. We view anxiety reduction in risk-taking to be a central function of delegated money management.

Of course, other conceptions of trust, and thus other modeling choices, are possible. One possibility is to assume that trust acts as an additive utility boost that the investor experiences from hiring his most trusted manager. In this formulation, trust is disconnected from risk-taking, implying that trusted managers will be hired even to invest in the riskless asset. In the Internet Appendix we formally compare this model to our setup. ${ }^{5}$ While this model does deliver the key prediction of negative market-adjusted returns from professional management, it does not yield other key predictions of our model, such as higher fees on riskier investment products and highpowered incentives to pander due to the sharing of perceived expected returns. Trust can also be modeled as providing a multiplicative boost to the net expected return $(R-f)$ that the investor obtains by delegating to a manager. This model is formally equivalent to the anxiety-reduction mechanism in that trust increases the risk the investor is willing to bear to earn an extra return. Of course, the interpretation of the two models is very different.

At $t=0$, the two money managers compete in fees to attract clients. Each manager $j=A, B$ optimally chooses what fee $f_{j}$ to charge per unit of assets managed. ${ }^{6}$ Based on the fees simultaneously set by managers, each investor optimally decides how much to invest in the risky asset and under which manager. At $t=1$, returns are realized and distributed to investors. Figure 1 summarizes this timeline. 


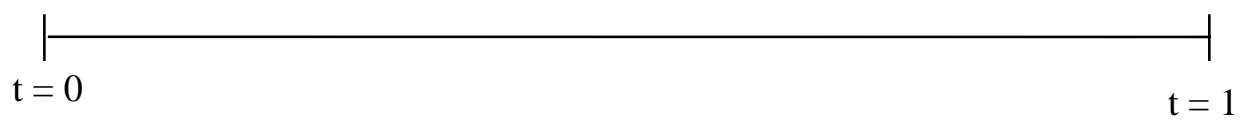

Each manager $j=\mathrm{A}$, B sets his fee $f_{j}$.

Returns are realized and

Each investor $i$ chooses his risky investment distributed to investors.

$x_{i}$ and his manager $j$.

Figure 1. Timeline.

\section{Equilibrium Fees and the Size of Money Management}

\section{A. The Investor's Portfolio Problem}

The expected utility of investor $i$ delegating to manager $j$ an amount $x_{i, j}$ of risky investment is equal to

$$
U_{i j}\left(x_{i, j}, f_{j}\right) \equiv R_{f}+x_{i, j}\left(R-f_{j}\right)-\frac{a_{i, j}}{2} x_{i, j}^{2} \sigma .
$$

The investor's excess return net of the management fee is equal to $R-f_{j}$. By investing in the riskless asset, the investor obtains no excess return and pays no fees.

Suppose that investor $i$ has hired manager $j$. Given the fee $f_{j}$, the investor who hires manager $i$ chooses a portfolio $\hat{x}_{i, j}$ maximizing $U\left(\hat{x}_{i, j}, f_{j}\right)$. This portfolio is given by

$$
\hat{x}_{i, j}=\frac{\left(R-f_{j}\right)}{a_{i, j} \sigma} \text {. }
$$

The optimal portfolio is riskier $\left(\hat{x}_{i, j}\right.$ is higher) if the investor hires a more trusted manager (having lower $a_{i, j}$ ). This effect plays a critical role in determining the fee structure. The utility obtained by investor $i$ under manager $j$ is then equal to

$$
U_{i j}\left(\hat{x}_{i, j}, f_{j}\right)=R_{f}+\frac{\left(R-f_{j}\right)^{2}}{2 a_{i, j} \sigma} .
$$

The investor chooses $A$ over $B$ provided that $U\left(\hat{x}_{i, A}, f_{A}\right) \geq U\left(\hat{x}_{i, B}, f_{B}\right)$, which is equivalent to

$$
\frac{a_{i, B}}{a_{i, A}} \geq \frac{\left(R-f_{B}\right)^{2}}{\left(R-f_{A}\right)^{2}}
$$


The investor chooses manager $A$ over manager $B$ provided that the investor's relative trust for $A$ is sufficient to compensate for the relative excess return (net of fee) expected under $B$. Because of constant absolute risk aversion, higher variance $\sigma$ of investment reduces overall risk-taking but not the choice between $A$ and $B$. That choice is pinned down only by the differential anxiety and excess return obtained by the investor with the two managers.

\section{B. Management Fees and Risk-Taking}

Denote by $x_{i, j}^{*}$ the optimal amount invested by $i$ under manager $j$ after a manager is optimally selected in light of equation (2), where $x_{i, j}^{*}=0$ if the investor hired manager $-j$. Then, at fee structure $\left(f_{A}, f_{B}\right)$, the profit of money manager $j$ charging $f_{j}$ is given by

$$
\pi_{j}\left(f_{A}, f_{B}\right)=f_{j} \cdot \int_{i} x_{i, j}^{*} d i
$$

which is the product of the fee $f_{j}$ and assets under management. The profits of manager $j$ depend on his competitor's fee $f_{-j}$ via the assets under management.

Let us derive the profits of $A$. If $A$ charges a higher fee than $B$, that is, if $f_{A} \geq f_{B}$, then the right-hand side of equation (2) is greater than one. Manager $A$ does not attract any $B$-trusting investors (for whom $a_{i, B} / a_{i, A}<1$ ); he can only attract some $A$-trusting investors. These are the investors who have sufficiently low trust in B that they prefer to stick with $A$ despite the higher fee, and are identified by the condition $\tau_{i} \leq\left(R-f_{A}\right)^{2} /\left(R-f_{B}\right)^{2}$. In this case, assets under $A$ 's management are given by

$$
\frac{\left(R-f_{A}\right)}{a \sigma} \cdot \int_{1-\theta}^{\max \left[1-\theta,\left(R-f_{A}\right)^{2} /\left(R-f_{B}\right)^{2}\right]} \frac{1}{2 \theta} d \tau .
$$

Expression (4) is the product of the wealth invested by each of the $A$-trusting investors times the measure of them that chooses manager $A$. When $f_{A} \geq f_{B}$, the profits of manager $A$ are the management fee $f_{A}$ times the wealth under management in equation (4). 
Consider now the case in which $A$ charges a lower fee than $B$, that is, $f_{A}<f_{B}$. Because the right-hand side of equation (2) is below one, manager $A$ attracts all $A$-trusting investors as well as some $B$-trusting investors. The latter investors are those with sufficiently high trust in $A$, that is, with $\tau_{i} \geq\left(R-f_{B}\right)^{2} /\left(R-f_{A}\right)^{2}$. By equation (1), each $B$-trusting investor places under $A$ 's management only a fraction $\tau_{i}$ of the wealth invested under $A$ by $A$-trusting investors. In this case, assets under $A$ 's management are given by

$$
\frac{\left(R-f_{A}\right)}{a \sigma} \cdot\left[\frac{1}{2}+\int_{\max \left[1-\theta,\left(R-f_{B}\right)^{2} /\left(R-f_{A}\right)^{2}\right]}^{1} \tau \cdot \frac{1}{2 \theta} d \tau\right] .
$$

Expression (5) is the sum of the assets invested by $A$-trusting investors plus the assets invested by the $B$-trusting investors who found it optimal to switch to $A$. When $f_{A}>f_{B}$, the profits of $A$ are equal to the product of the management fee $f_{A}$ and the assets under management in (5).

Putting the above together, for any $\left(f_{A}, f_{B}\right)$, the profits $\pi_{A}\left(f_{A}, f_{B}\right)$ of manager $A$ are given by

$$
\left\{\begin{array}{ll}
f_{A} \cdot \frac{\left(R-f_{A}\right)}{a \sigma} \cdot \frac{\max \left[1-\theta,\left(R-f_{A}\right)^{2} /\left(R-f_{B}\right)^{2}\right]-(1-\theta)}{2 \theta} & \text { if } f_{A} \geq f_{B} \\
f_{A} \cdot \frac{\left(R-f_{A}\right)}{a \sigma} \cdot\left[\frac{1}{2}+\frac{\left.1-\max \left[1-\theta,\left(R-f_{B}\right)^{2} /\left(R-f_{A}\right)^{2}\right]^{2}\right]}{4 \theta}\right] & \text { if } f_{A}<f_{B}
\end{array} .\right.
$$

The profit of manager $A$ increases in the fee charged by $B$, since a higher $f_{B}$ reduces investors' net excess return under $B$, thus increasing $A$ 's clientele. In contrast, a higher $f_{A}$ exerts an ambiguous effect on the profits of $A$. On the one hand, it increases the surplus extracted by the manager; on the other hand, it reduces assets under management (by reducing both investment by his clients on the intensive margin and the size of his clientele on the extensive margin).

The profits of manager $A$ increase in the risky asset's gross excess return: a higher $R$ encourages any investor to put more money under management, which increases the preference of $A$-trusting investors for $A$. Indeed, manager $A$ allows these investors to take more risk than manager $B$ by reducing their anxiety, which is particularly valuable when the excess return is high. Second, a higher dispersion of trust $\theta$ exerts an ambiguous effect on profits - it increases them when $A$ offers a lower net return than $B\left(f_{A} \geq f_{B}\right)$, but decreases them otherwise. 
By the same logic, at any $\left(f_{A}, f_{B}\right)$, the profit $\pi_{B}\left(f_{A}, f_{B}\right)$ of manager $B$ is equal to

$$
\left\{\begin{array}{ll}
f_{B} \cdot \frac{\left(R-f_{B}\right)}{a \sigma} \cdot\left[\frac{1}{2}+\frac{\left.1-\max \left[1-\theta,\left(R-f_{A}\right)^{2} /\left(R-f_{B}\right)^{2}\right]^{2}\right]}{4 \theta}\right] & \text { if } f_{A} \geq f_{B} \\
f_{B} \cdot \frac{\left(R-f_{B}\right)}{a \sigma} \cdot \frac{\max \left[1-\theta,\left(R-f_{B}\right)^{2} /\left(R-f_{A}\right)^{2}\right]-(1-\theta)}{2 \theta} & \text { if } f_{A}<f_{B}
\end{array} .\right.
$$

The properties of (7) are analogous to those just discussed in the case of equation (6).

Given profits $\pi_{A}\left(f_{A}, f_{B}\right)$ and $\pi_{B}\left(f_{A}, f_{B}\right)$, a competitive equilibrium in pure strategies is a Nash Equilibrium in which each manager $j$ optimally sets his fee $f_{j}$ by taking his competitor's equilibrium fee $f_{-j}^{*}$ as given. Formally, an equilibrium is a profile of fees $\left(f_{A}^{*}, f_{B}^{*}\right)$ such that

$$
\begin{aligned}
& f_{A}^{*} \in \operatorname{argmax}_{f_{A}} \pi_{A}\left(f_{A}, f_{B}^{*}\right) \\
& f_{B}^{*} \in \operatorname{argmax}_{f_{B}} \pi_{B}\left(f_{A}^{*}, f_{B}\right)
\end{aligned} .
$$

There is a unique symmetric competitive equilibrium in our model, characterized below. All proofs are collected in the Internet Appendix.

PROPOSITION 1: In the unique, symmetric, equilibrium of the model, fees are equal to

$$
f_{A}^{*}=f_{B}^{*}=\left(\frac{\theta}{1+\theta}\right) \cdot \frac{R}{2}
$$

Each investor delegates his portfolio to his most trusted manager. The total value of assets under management, equally split between $A$ and $B$, is given by

$$
\int_{i}\left(x_{i, A}^{*}+x_{i, B}^{*}\right) d i=\left(\frac{2+\theta}{1+\theta}\right) \cdot \frac{R}{2 a \sigma} .
$$

The fee charged by each manager is a constant fraction of the expected excess return $R$ (above the riskless rate). Intuitively, the manager extracts part of the expected surplus $R$ that he enables the investor to access. The equilibrium fee does not depend on $a$ : the ability of a manager to extract rents from his trusting clients does not depend on their level of anxiety, but on the increase in their anxiety when they switch managers. Parameter $\theta$ captures exactly this point. In fact, the fraction of excess return extracted by the manager increases in $\theta$. When $\theta=0$, all investors trust the two managers equally, so competition between identical managers drives equilibrium fees to 
zero. In contrast, when $\theta>0$, fees are positive. Now investors bear an anxiety cost of leaving their more trusted manager, which allows him to charge a positive fee. However, investors take more risk with their more trusted manager than with the less trusted one (or on their own). At the maximal dispersion of trust $(\theta=1)$, the two managers have huge market power and extract $1 / 4$ of the excess return from their investors. The model predicts that fees should be higher in sectors in which dispersion of trust is higher, perhaps owing to the absence of a market index or of established measures of risk.

In our model, management fees are not compensation for abnormal returns (alpha) but rather a way to share the risk premium between the investor and the manager. The gross return of the managed portfolio equals the market excess return $R$, but the net return exhibits negative alpha once fees are netted out. The model thus immediately delivers the most fundamental fact about delegated portfolio management, namely, that professional managers on average earn negative market-adjusted returns net of fees. The reason is that investors are willing to pay for anxiety reduction rather than for alpha.

The size of the money management industry (see equation (9)) increases in the excess return $R$, decreases in the general level of distrust or anxiety $a$, and decreases in the dispersion of trust $\theta$. A higher $R$ increases the surplus generated by the risky investment, which increases risktaking. At the same time, an increase in $R$ increases fees, which decrease risk-taking. The former effect dominates, so that higher excess return $R$ boosts the size of the industry. ${ }^{7}$

A higher general level of trust (a lower $a$ ) increases the size of the industry, bringing more assets out of the mattresses and into the financial system, a finding documented empirically by Guiso, Sapienza, and Zingales (2004, 2008). Even though the overall level of trust does not affect equilibrium fees, it shapes the extent of financial intermediation in the economy. More differentiated trust across managers, as captured by a higher $\theta$, increases their market power and management fees, and thus reduces the size of the industry. Conditional on investors' trust in their preferred money manager, assets under management are too small owing to management fees. 
To consider welfare implications, we compute the change in investor welfare that occurs when trusted money managers are made available, relative to a world in which delegation is not possible.

COROLLARY 1: The presence of money managers improves investors' welfare relative to a world in which everyone invests on his own. The social benefit of money management is equal to

$$
\frac{R^{2}}{8 a \sigma}\left(\frac{2+\theta}{1+\theta}\right)^{2}
$$

The benefit of money management is to increase risk-taking. This benefit is increasing in the expected return per unit of risk $R / \sqrt{\sigma}$, decreasing in average anxiety experienced with the most trusted manager $a$, and decreasing in $\theta$.

The basic model might thus shed light on the central finding of the literature on financial advice, namely, that many investors seek it despite extremely high cost and poor investment performance (Bergstresser, Chalmers, and Tufano (2009), Chalmers and Reuter (2012), Del Guercio, Reuter, and Tkac (2010)). In our view, investors see themselves as better off with the advice than without it since advice alleviates their anxiety about risk and enables them to take more risk. Chalmers and Reuter (2012) actually show empirically that, among the investors predicted based on their demographic characteristics to use financial advisors, those who actually use them hold portfolios with higher betas ( 0.4 higher) than those who do not use advice. As investors are increasingly asked to choose how to allocate their savings, rather than participate in, say, defined benefit plans, they need to make choices about risky investments or just put money in the bank. Financial advice in our model helps them take risk, even when it is generic (or worse). With positive expected returns to risk-taking, advice makes investors better off.

The welfare analysis in Corollary 1 views investor trust in managers as a legitimate source of utility (e.g., reflecting the manager's true tighter distribution on asset returns). One might object to this assumption, arguing that trust is at least in part illusory due to investors' misplaced confidence in the manager's expertise. Even in this case, however, the presence of money 
managers may improve investors" “objective" welfare. Although blind trust may distort investment decisions (sometimes inducing too much risk-taking), it still allows investors to access a risky asset with a higher expected return and experience lower anxiety than they could on their own. A full discussion of this case is beyond the scope of this paper.

\section{Multiple Financial Products}

So far, we have allowed money managers to offer investors a single, well-diversified risky portfolio (e.g., the S\&P 500). In reality, institutions such as mutual fund families, financial planners, funds of funds, and brokerage firms offer a broad range of assets and sector-specific investment options, and investors individually choose how much to invest in each. To understand this practice, we allow money managers to break down their product line into specialized asset classes and then let investors choose between them. These asset classes are also portfolios assembled by the manager, so trust is still important. Individual asset classes, however, are not fully diversified (e.g., they consist of only industrial or high-tech stocks). In this setting, we ask two questions. First, does fee-setting by money managers distort investors' mix of different sectorspecific funds? Second, how do optimal fees depend on sector-specific risk and return?

The formal structure works as follows. There are two uncorrelated risky assets (or, more appropriately, asset classes) 1 and 2. Asset $z=1,2$ yields excess return $R_{z}$ with variance $\sigma_{z}$. There is a positive relationship between risk and expected return. In particular, asset 1 has lower risk and expected return than asset 2 , that is, $R_{2} \geq R_{1}$ and $\sigma_{2} \geq \sigma_{1}$. Let $x_{z, i}$ be the wealth invested by a generic investor $i$ in asset $z=1,2$. We then have the following lemma.

LEMMA 1: For any total amount $x_{1, i}+x_{2, i}$ of risky investment, investors' optimal portfolio places a relative share $\frac{x_{1, i}}{x_{2, i}}=\left(\frac{R_{1}}{\sigma_{1}}\right) /\left(\frac{R_{2}}{\sigma_{2}}\right)$ of wealth in asset 1 relative to asset 2 .

This optimal portfolio represents the normative benchmark of our analysis, under the assumptions of rational expectations and no management fees. In this respect, we can view the 
excess return $R$ and the variance $\sigma$ of the risky asset in the previous section as those delivered by the optimal portfolio of Lemma 1.

Money managers offer assets 1 and 2 separately, and at different fees, to investors. At $t=0$, each manager $j=A, B$ optimally sets the fees $\left(f_{1, j}, f_{2, j}\right)$ for investing in asset 1 and 2 , respectively. Given fees $\left(f_{1, j}, f_{2, j}\right)$, each investor $i$ decides whether to invest in asset $z=1,2$ under manager $A$ or $B$ and how much to invest in each asset. By so doing, investors choose - in a decentralized fashion - the composition of their portfolios. Managers affect portfolios via the equilibrium fee structure $\left(f_{1, j}, f_{2, j}\right)$. We assume that investors correctly perceive the return of different assets, but relax this assumption in Section IV.

Denote by $x_{i, j, z}$ investor $i$ 's risk-taking in asset $z=1,2$ under manager $j=A, B$. Given the management fee $f_{z, j}$, the analysis of Section II implies that an investor who has hired manager $j$ to invest in asset class $z$ will choose

$$
\hat{x}_{i, j, z}=\frac{\left(R_{z}-f_{z, j}\right)}{a_{i, j} \sigma_{z}} .
$$

The investor places more wealth in the asset having the highest expected excess return (net of fees) per unit of risk. The analysis of Section II immediately implies that a generic investor $i$ delegates his investment in asset $z$ to manager A (rather than B) when

$$
\frac{a_{i, B}}{a_{i, A}} \geq \frac{\left(R_{z}-f_{z, B}\right)^{2}}{\left(R_{z}-f_{z, A}\right)^{2}}
$$

that is, when the relative trust of investor $i$ in manager $A$ is sufficient to compensate for the relative expected excess return promised by $B$ on risky asset $z$.

Define $x_{i, j, z}^{*}$ as the optimal investment after (11) is taken into account. Then, at $t=0$, money managers set their fees $\left(f_{1, A}, f_{2, A}, f_{1, B}, f_{2, B}\right)$. The profit of money manager $j$ is equal to

$$
\pi_{j}\left(f_{1, A}, f_{2, A}, f_{1, B}, f_{2, B}\right)=f_{1, j} \cdot \int_{i} x_{i, j, 1}^{*}+f_{2, j} \cdot \int_{i} x_{i, j, 2}^{*}
$$

which is the sum of the fees obtained from assets under management in the two risky assets. 
Given the additive objective function in (12), manager $A$ maximizes the sum of two profit functions - one for asset 1 , the other for asset 2 - each of which is identical to that in equation (6) but defined for a different return-variance configuration. The same principle holds for manager $B$, whose overall profit function adds two asset-specific versions of equation (7). By solving for the Nash Equilibrium of this game, we can characterize the market equilibrium as follows.

PROPOSITION 2: In the unique, symmetric, competitive equilibrium, fees are given by

$$
f_{z, A}^{*}=f_{z, B}^{*}=\left(\frac{\theta}{1+\theta}\right) \cdot \frac{R_{z}}{2} .
$$

Investors take risk only with their most trusted manager and they select asset shares

$$
\frac{x_{i, j, 1}^{*}}{x_{i, j, 2}^{*}}=\frac{R_{1} / \sigma_{1}}{R_{2} / \sigma_{2}}, \quad \text { for all } i, j .
$$

The total amount of assets managed (equally split between $A$ and $B$ ) is equal to

$$
\int_{i} \sum_{z=1,2}\left(x_{i, A, z}^{*}+x_{i, B, z}^{*}\right) d i=\left(\frac{2+\theta}{1+\theta}\right) \cdot \sum_{z=1,2} \frac{R_{z}}{2 a \sigma_{z}}
$$

From equation (13), it is clear that money managers extract a fixed share of the expected return above the riskless rate of any asset they offer to investors. As a consequence, our model accounts for the fact that money managers charge higher unit fees for investing in asset classes with higher risk and higher expected return. For example, Bogle (1998) finds that higher expense ratio bond funds tend to offset their higher fees by taking both more credit risk and more duration risk. This is exactly the prediction of our model under the reasonable assumption that higher risk entails higher expected return. Our model further predicts that the link between fees and returns should be steeper when trust dispersion $\theta$ is higher. Perhaps this prediction might shed light on incentive fees in hedge funds and private equity funds, where trust plays such a fundamental role in mediating investments.

Interestingly, optimal fees do not distort portfolios: investors mix the two assets as in Lemma 1 (see equation (14)). This is because the manager extracts the same fraction of the 
expected return from both asset classes, without affecting their relative expected returns. Total fees do not change relative to the case in which managers offer just the portfolio of Lemma 1 . These results change when investors misperceive the expected returns of different assets.

\section{Biased Expectations of Asset Returns and Pandering}

We next investigate a model in which investors do not hold rational expectations regarding the relative returns of asset classes, but money managers do. Investors might extrapolate returns on some assets and chase categories that previously performed well, or seek to invest in new products. Extrapolation has been discussed extensively in behavioral finance with respect to both individual securities and markets (Lakonishok, Shleifer, and Vishny (1994), Barberis, Shleifer, and Vishny (1998)) and mutual funds (Frazzini and Lamont (2008)).

We capture this idea by assuming that investors believe that the excess return of asset class (or "asset" for simplicity) $z$ is $R_{z, e}$, where subscript $e$ denotes investors' expectation. Beliefs are erroneous whenever $R_{z, e} \neq R_{z}$ for at least one asset $z=1,2$. The perception of variances is correct. We focus on the case in which investors invert the ranking of expected returns, that is, $R_{1, e} \geq R_{2, e}$. Since asset 2 delivers the higher objective return, investors inflate the return per unit of risk of asset $1\left(R_{1, e} / R_{2, e} \geq R_{1} / R_{2}\right)$. We refer to asset 1 as the "hot asset" and asset 2 as the "cold asset." This implies that investment in asset 2 is most profitable (with extrapolative expectations, this is due to mean reversion). The best strategy from the investor's viewpoint is contrarian.

By allowing for investor misperceptions we can ask whether money managers find it profitable to pander to investor tastes, or whether they choose fee structures that correct investor errors. Answering this question may allow us to address what appears to be the empirically relevant possibility of investment advisors underperforming passive strategies even before fees (Malkiel (1995), Gil-Bazo and Ruiz-Verdú (2009), Del Guercio, Reuter, and Tkac (2010)), as well as study the determinants of product proliferation in the money management industry. We proceed in two steps. To begin, we study the incentives to pander by assuming that managers face only the one- 
period problem considered so far. The analysis of Section IV.A highlights the basic incentive for managers to pander in that model. Section IV.B extends the basic model by having money managers operate for two periods. This allows us to incorporate into our setup the conventional view that managers have an incentive to act as contrarians in order to establish a reputation for being skilled. This extension allows us to directly compare the short-run incentive of managers to pander with the mitigating long-run incentive to establish a reputation.

\section{A. Investors' Misperceptions, Product Proliferation, and Pandering with Short Horizons}

The setup here is the same as in our previous analysis, except that now investors misperceive excess returns. To gauge the implication of this change, it suffices to note that risktaking by investors in equation (10) and their choice of manager in equation (11) are shaped by the

perceived return $R_{z, e}$ of asset (class) $z$ and not by its true return $R_{z}$. As a consequence, management fees are equal to a constant fraction of investors' perceived return,

$$
f_{z, A}^{*}=f_{z, B}^{*}=\left(\frac{\theta}{1+\theta}\right) \cdot \frac{R_{z, e}}{2}
$$

and investors allocate their wealth across assets according to their perceived returns,

$$
\frac{x_{i, j, 1}^{*}}{x_{i, j, 2}^{*}}=\frac{R_{1, e} / \sigma_{1}}{R_{2, e} / \sigma_{2}} .
$$

In this situation, the following property holds.

COROLLARY 2: In the unique, symmetric, equilibrium prevailing when managers offer the two assets separately, fees are higher for investing in the hot asset than in the cold asset and investors place too much wealth in the hot asset relative to the benchmark of Lemma 1.

Because managers optimally extract a constant fraction of an asset's perceived expected return, total fees are higher for "hot" assets, such as growth stocks as compared to value stocks, or specialty funds compared to diversified funds, but investors still want to disproportionally invest in them. Money managers maximize their profits by encouraging, or at least not discouraging, 
investors to take excessive risks in hot asset classes. In this sense, money managers pander to investors' biases rather than correct them. ${ }^{8}$

Money managers could correct investor misperceptions by setting a sufficiently high fee in the hot asset class that investors choose to hold the two assets in the proportions dictated by Lemma 1 (or they could offer investors the optimal portfolio of Lemma 1). To see why managers have no incentive to do so, consider their equilibrium profits. Given the perceived returns $\left(R_{1, e}, R_{2, e}\right)$, a manager's profit is proportional to the average squared perceived return across the two assets,

$$
\frac{1}{2} \cdot \sum_{z=1,2} \frac{R_{z, e}^{2}}{\sigma_{z}}
$$

A manager's profits are quadratic in expected returns $R_{z, e}$. Intuitively, a higher perceived expected return increases profits by both i) increasing the fee charged by the manager, and ii) increasing the asset base over which the fee is collected. Equation (17) implies that the manager benefits from the investor chasing hot asset classes, which more than compensates for underinvestment in cold assets.

Corollary 2 might help account for a great deal of evidence mentioned in the introduction about poor performance of mutual funds, their high fees, and the negative relationship between performance and fees. Poor performance in our model results from investing in overvalued assets, which investors prefer when they form extrapolative expectations. Such a portfolio allocation in turn enables managers or advisors to charge higher fees. In fact, in our model higher fees are precisely a consequence of managers pandering to investor preferences for assets that are overvalued. The model thus accounts for the findings of Gil-Bazo and Ruiz-Verdú (2009) and Del Guercio, Reuter, and Tkac (2010). It is also consistent with the evidence in Mullainathan, Noeth, and Schoar (2012) that advisors direct investors toward hot sector funds.

Both the proliferation of investment options and the prevalence of fund families naturally arise in our model. Mutual fund families can be interpreted as a vehicle to harness trust and increase profits across multiple asset classes (Massa (2003)). Proliferation of investment options within asset classes helps raise demand for risky assets (and fees) from trusting investors who chase 
returns. The same interpretation would apply to private wealth management firms with extensive in-house portfolio capabilities. A trusted advisor has a strong incentive to offer a wide range of products to his clients, who can then move funds around while paying the advisor's fees.

\section{B. Investor Extrapolation and Pandering by Money Managers with Long Horizons}

Conventional wisdom holds that managers benefit from investing in undervalued assets because doing so allows them to earn superior returns, establish a reputation for being skilled, and attract clients. We now introduce this motivation for contrarianism into our model by allowing managers to earn positive alpha, thus enabling investors to update their estimates of skill based on past performance. We show that trust encourages pandering. When trust is important, managers can extract such high fees from pandering that the long-run incentive for contrarianism is too weak. ${ }^{9}$

There are three periods $t=0,1,2$ and two generations of investors that live for one period; one generation is born at $t=0$, and the other at $t=1$. Managers select portfolios for their clients, so that pandering is equivalent to the manager tilting his portfolio towards the hot asset class. At the cost of greater complexity, we could have continued with the previous model where pandering works through fees.

At $t=0$, each manager sets a portfolio and a fee for the first generation of investors, who choose which manager to hire. At $t=1$, investors belonging to the new generation are born, they update their beliefs on managers' abilities based on interim returns, and they choose managers. Returns do not affect trust, so the distribution of trust among investors toward managers $A$ and $B$ is the same at $t=0$ and $t=1$. The realized return of asset $z=1,2$ at $t=1,2$ under manager $j=A, B$ is given by

$$
\tilde{R}_{z, j, t}=R_{z}+V_{j}+\epsilon_{j, t}
$$

In (18), $R_{z}$ is the excess return of asset class $z, V_{j}$ is the additional expected return arising from the ability of manager $j$, and $\epsilon_{j, t}$ is a serially uncorrelated shock capturing the manager's luck. Both 
managers and investors are uninformed about $V_{j}$, which is normally distributed with mean zero and variance $v$ at $t=0$. The distribution of luck $\epsilon_{j, t}$ is also normal, with mean zero and variance $\eta$. Skill here is best viewed as capturing the ability to assemble a portfolio within an asset class.

In equation (18), all volatility in returns is manager-specific, so there is no motive for diversifying portfolios across asset classes $z=1,2$. We could add a diversification motive to the model, but at the cost of added complexity. The optimal strategy here is to invest only in the undervalued asset 2. A pandering manager, however, invests only in the overvalued asset 1 , just as in the one-period model of Section IV.A. Denote by $\omega_{j}$ the portfolio share that manager $j$ invests in asset class 1. The manager charges a fee equal to $\varphi_{j} R_{j}$, where $\varphi_{j}$ is the fee per unit of return. Expressing fees in this way renders the model more tractable without affecting our results.

To solve the model, consider how investors assess managerial ability after observing portfolio returns at $t=1$. An investor attributes any difference between the expected and realized return $\widetilde{R}_{j, 1}$ to skill or luck according to Bayesian updating. ${ }^{10}$ As a consequence, at $t=0$, manager $j$ knows that his assessed ability at $t=1$ is normally distributed with mean

$$
\mathbb{E} \tilde{V}_{j}=\left[\omega_{j}\left(R_{1}-R_{1, e}\right)+\left(1-\omega_{j}\right)\left(R_{2}-R_{2, e}\right)\right]\left(\frac{v}{v+\eta}\right)
$$

and variance $v$. The manager can boost his average assessed ability $\mathbb{E} \tilde{V}_{j}$ by investing more in the undervalued asset 2. Indeed, if the manager invests in an asset that investors are too optimistic about, the future disappointing returns will be attributed to low managerial skill rather than the asset itself. In contrast, contrarianism creates a positive abnormal expected return $\left(R_{2}-R_{2, e}\right)$ that leads investors to upgrade their estimates of managerial skill. ${ }^{11}$ This is the classic motive for contrarianism, which in our model conflicts with the incentive to pander described in Section III.

The timeline of the model is as follows. Denote by $\left(\varphi_{j}, \omega_{j}\right)$ the fee and portfolio chosen by manager $j$ at $t=0$, and by $\left(\varphi_{j}^{\prime}, \omega_{j}^{\prime}\right)$ the fee and portfolio chosen by manager $j$ at $t=1$. The sequence of events in our model is graphically represented in Figure 2. 


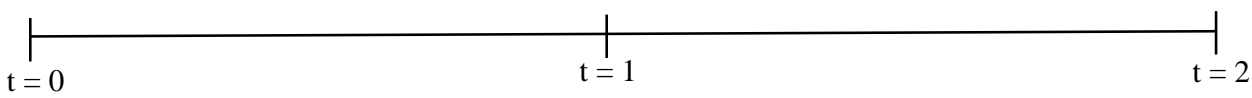

Each manager $j=\mathrm{A}, \mathrm{B}$ sets his fee and portfolio $\left(\varphi_{j}, \omega_{j}\right)$

Investors choose a manager.
Returns on portfolios are realized, new investors assess managerial ability.

Each manager $j=\mathrm{A}$, B sets a new fee and portfolio $\left(\varphi_{j}^{\prime}, \omega_{j}^{\prime}\right)$.

New investors choose a manager.
Returns on portfolios are realized.

\section{Figure 2. Timeline of the model with managerial skill.}

We solve the model backwards, starting with the final period $t=1$. After the returns $\left(\tilde{R}_{A, 1}, \tilde{R}_{B, 1}\right)$ on initial portfolios are realized, investors form average ability assessments $\left(\tilde{V}_{A}, \tilde{V}_{B}\right)$. Given these assessments, each manager assembles a new portfolio $\omega_{j}^{\prime}$ and sets a fee $\varphi_{j}^{\prime}$.

At $t=0$, the timing above creates a tension between two forces. From the viewpoint of future profits, a manager has an incentive to be contrarian in order to enhance his assessed skill, which allows him to attract more investments and charge higher fees at $t=1$. In contrast, from the viewpoint of current profits, the manager has an incentive to pander in order to attract more investment and charge higher fees at $t=0$. Proposition 3 shows that in our model the incentive to be contrarian always dominates when there is no manager-specific trust.

PROPOSITION 3: In the absence of manager-specific trust, i.e., $\theta=0$, there is never an equilibrium in which both managers pander to investors, i.e., $\omega_{A}=\omega_{B}=1$.

When $\theta=0$, managers engage in Bertrand competition. As a consequence, even if both managers pander, their profits at $t=0$ are equal to zero. Each manager then sees no cost of deviating to contrarianism. Even if contrarianism causes a manager to lose current clients, it does not reduce his current profits, which are zero anyway. The benefit of contrarianism is still material, however, even if investors are fully mobile $(\theta=0)$ : the manager deviating to the undervalued asset can extract a 
fee thanks to his perceived higher ability in the future. Hence, in the absence of manager-specific trust, there is no equilibrium in which both managers pander.

Matters change when manager-specific trust is present. Now pandering allows managers to extract rents from their clients at $t=0$, so that the cost of being contrarian is positive. This suggests that now both managers may choose to pander. Unfortunately, we cannot perform a general analysis of the case in which $\theta>0$ because dynamic updating of fees and the nonlinearity of fund flows render the model intractable. To shed light on the intuition for why the presence of trust can allow for the existence of equilibria in which both managers pander, consider the extreme case in which trust is so strong that investors are fully attached to their preferred managers. This amounts to assuming that all investors have $\tau_{i}=0$, so that they are all maximally unwilling to leave their trusted manager. This assumption is more extreme than setting $\theta=1$, because the latter case still allows many investors in the middle of the distribution to trust both managers.

When all investors have $\tau_{i}=0$, investors are fully immobile and each manager acts as an intertemporal monopolist. If he panders, he extracts fees related to investor misperceptions at $t=0$. At the same time, his assessed ability will decline in expectation. As a result, even if the manager is a monopolist and his clients do not leave him, he is hurt by skill downgrades, which reduce the amount of capital his clients give him to manage in the future. In this sense, pandering still entails a cost to the manager. The Internet Appendix proves the following proposition.

PROPOSITION 4: In the case of monopolistic managers, the equilibrium in which both managers pander arises if and only if managers are sufficiently impatient ( $\delta$ is sufficiently low) and/or the signal-to-noise ratio $v / \eta$ is sufficiently low. In particular, when the two assets are equally misvalued, that is, $\left(R_{2}-R_{2, e}\right)=\left(R_{1, e}-R_{1}\right)$, pandering arises if and only if

$$
\delta \cdot \frac{v \cdot(v+\eta)}{\eta \cdot(2 v+\eta)}<\frac{R_{1, e}^{2}-R_{2, e}^{2}}{\left[\left(R_{2}-R_{2, e}\right)+\left(R_{1, e}-R_{1}\right)\right] \cdot 2 \cdot R_{1, e}}
$$


In the case of super-high trust described by Proposition 4, the incentive to pander can be so strong that no manager chooses to be contrarian. Because trust fully ties investors to their own managers, each manager can charge high fees that extract part of the perceived excess return delivered to his clients. At $t=0$ then, the manager chooses the strategy - pandering or contrarianism - that yields in expectation over time the larger perceived excess return. In line with this intuition, equation (20) says that the manager prefers pandering to contrarianism when: i) his intertemporal discount rate is high (i.e., $\delta$ is low), or ii) the signal-to-noise ratio of managerial skill is low (i.e., $v / \eta$ is low). Both factors reduce the return to contrarianism relative to that of pandering. ${ }^{11}$

In sum, the model says that when fees/profits are low, money managers have an incentive to gain market share in the future by investing in undervalued assets today. When, in contrast, fees/profits are high, money managers may have an incentive to exploit their current market power by pandering to investors' beliefs. These different equilibrium configurations have important social welfare implications. Because the return in the cold sector is higher than in the hot one (i.e., $R_{2}>R_{1}$ ), managers behaving as "benevolent doctors" facilitate desirable financial intermediation, while panderers "abuse" investor trust, reducing social welfare.

\section{Implications}

An important message of Section IV is that, in many circumstances, managers have a strong incentive to pander to their investors' beliefs. The incentive for contrarianism is much weaker than it would be if clients were foot-loose. In situations in which investor beliefs are misguided and highly correlated across investors, money managers pursue similar strategies that pander to these misguided beliefs while dividing the market based on the trust of their clients.

This message has a number of significant implications. First, it suggests that the forces of arbitrage in financial markets might be weaker than one might have thought. Previous research focuses on the limits of arbitrage because arbitrage is risky, or because arbitrageurs have limited 
access to capital (e.g., De Long et al. (1990), Shleifer and Vishny (1997)). Here we show that, in effect, professional money managers who are perfectly capable of arbitrage themselves turn into noise traders, because doing so brings them higher fees from their trusting investors. With massive amounts of investor wealth guided by such trust relationships, capital following noise trading strategies is increased, and arbitrage capital correspondingly diminished. In equilibrium, markets become more volatile.

Second, when many investors seek a particular hot product, such as internet stocks or bonds promising a higher yield without extra risk, competing money managers cater to these demands and help destabilize prices. The technology bubble in the U.S. saw mutual funds shifting into technology stocks, and even so-called "value investors" turning to "growth-at-the-right-price" strategies, which essentially amounted to chasing the bubble. More recently, prime money market funds shifted into short-term "safe" liabilities of financial institutions yielding higher rates than Treasury bills. We have not modeled endogenous price determination here, but one can see how such investment strategies can be destabilizing. In particular, as more money managers cater to investor beliefs, prices of securities that investors favor will tend to rise, which will only encourage these strategies in the short run, as well as improve managerial reputations (see Barberis and Shleifer (2003)). The long run over which contrarianism pays will become even longer and less attractive from the viewpoint of profit-maximizing managers.

We should not forget, however, the central point of trust-mediated money management that it enables investors to take risks, and earn returns, that they might otherwise not obtain. There are surely significant distortions in portfolio allocation, which are inevitable when investors exhibit psychological biases. Despite these distortions, financial advice and money management represent an important service. The growth of the financial industry, described most recently by Philippon (2012) and Greenwood and Scharfstein (2013), might first and foremost reflect the growing demand for this service as investor wealth and trust in markets have increased over time. 


\section{REFERENCES}

Asness, Clifford, Robert Krail, and John Liew, 2001, Do hedge funds hedge? Journal of Portfolio Management 28, 6-19.

Barberis, Nicholas, and Andrei Shleifer, 2003, Style investing, Journal of Financial Economics 68, $161-199$.

Barberis, Nicholas, Andrei Shleifer, and Robert Vishny, 1998, A model of investor sentiment, Journal of Financial Economics 49, 307-343.

Basak, Suleyman, and Domenico Cuoco, 1998, An equilibrium model with restricted stock market participation, Review of Financial Studies 11, 309-341.

Bergstresser, Daniel, John Chalmers, and Peter Tufano, 2009, Assessing the costs and benefits of brokers in the mutual fund industry, Review of Financial Studies 22, 4129-4156.

Berk, Jonathan, and Richard Green, 2004, Mutual fund flows and performance in rational markets, Journal of Political Economy 112, 1269-1295.

Bhattacharya, Utpal, Andreas Hackethal, Simon Kaesler, Benjamin Loos, and Steffen Meyer, 2012, Is unbiased financial advice to retail investors sufficient? Answers from a large field study, Review of Financial Studies 25, 975-1032.

Bikhchandani, Sushil, David Hirshleifer, and Ivo Welch, 1992, A theory of fads, fashion, custom, and cultural change as information cascade, Journal of Political Economy 100, 992-1026.

Blake, Christopher, Edwin Elton, and Martin Gruber, 1993, The performance of bond mutual funds, Journal of Business 66, 370-403.

Bogle, John, 1998, Bond funds: Treadmill to oblivion? Speech before the Fixed Income Analysts Society, Inc. March 18.

Calvet, Laurent, John Campbell, and Paolo Sodini, 2007, Down or out: Assessing the welfare costs of household investment mistakes, Journal of Political Economy 115, 707-747.

Campbell, John, 2006, Household finance, Journal of Finance 61, 1553-1604. 
Canes-Wrone, Brandice, Michael Herron, and Kenneth Shotts, 2001, Leadership and pandering: A theory of executive policymaking, American Journal of Political Science 45, 532-550.

Carlin, Bruce, 2009, Strategic price complexity in retail financial markets, Journal of Financial Economics 91, 278-287.

Chalmers, John, and Jonathan Reuter, 2012, What is the impact of financial advisors on retirement portfolio choices and outcomes? Working paper, University of Oregon and Boston College.

Chevalier, Judith, and Glenn Ellison, 1997, Risk taking by mutual funds as a response to incentives, Journal of Political Economy 105, 1167-1200.

Chevalier, Judith, and Glenn Ellison, 1999, Career concerns of mutual fund managers, Quarterly Journal of Economics 114, 389-432.

Cuoco, Domenico, and Ron Kaniel, 2011, Equilibrium prices in the presence of delegated portfolio management, Journal of Financial Economics 101, 264-296.

Dasgupta, Amil, and Andrea Prat, 2006, Financial equilibrium with career concerns, Theoretical Economics 1, 67-93.

Dasgupta, Amil, Andrea Prat, and Michela Verardo, 2011a, The price impact of institutional herding, Review of Financial Studies 24, 892-925.

Dasgupta, Amil, Andrea Prat, and Michela Verardo, 2011b, Institutional trade persistence and longterm equity returns, Journal of Finance 66, 635-653.

De Long, Bradford, Andrei Shleifer, Lawrence Summers, and Robert Waldmann, 1990, Noise trader risk in financial markets, Journal of Political Economy 98, 703-738.

Del Guercio, Diane, Jonathan Reuter, Paula Tkac, 2010, Broker incentives and mutual fund market segmentation, NBER Working paper 16312.

Frazzini, Andrea, and Owen Lamont, 2008, Dumb money: Mutual fund flows and the cross-section of returns, Journal of Financial Economics 88, 299-322.

French, Kenneth, 2008, Presidential address: The cost of active investing, Journal of Finance 63, $1537-1573$. 
Gabaix, Xavier, and David Laibson, 2006, Shrouded attributes, consumer myopia, and information suppression in competitive markets, Quarterly Journal of Economics 121, 505-540.

Georgarakos, Dimitris, and Roman Inderst, 2011, Financial advice and stock market participation, European Central Bank Working paper 1296.

Gil-Bazo, Javier, and Pablo Ruiz-Verdú, 2009, The relation between price and performance in the mutual fund industry, Journal of Finance 64, 2153-2183.

Greenwood, Robin, and David Scharfstein, 2013, The growth of modern finance, Journal of Economic Perspectives 27, 3-28.

Greenwood, Robin, and Andrei Shleifer, 2014, Expectations of returns and expected returns, Review of Financial Studies 27, 714-746.

Gruber, Martin, 1996, Another puzzle: The growth in actively managed mutual funds, Journal of Finance 51, 783-810.

Guerrieri Veronica, and Péter Kondor, 2012, Fund managers, career concerns and asset price volatility, American Economic Review 102, 1986-2017.

Guiso, Luigi, Paola Sapienza, and Luigi Zingales, 2004, The role of social capital in financial development, American Economic Review 94, 526-556.

Guiso, Luigi, Paola Sapienza, and Luigi Zingales, 2008, Trusting the stock market, Journal of Finance 63, 2557-2600.

Hackethal, Andreas, Michael Haliassos, and Tullio Jappelli, 2012, Financial advisors: A case of babysitters? Journal of Banking and Finance 36, 509-524.

Hackethal, Andreas, Roman Inderst, Steffen Meyer, 2012, Trading on advice, Working paper, University of Frankfurt.

Hortacsu, Ali, and Chad Syverson, 2004, Product differentiation, search costs, and competition in the mutual fund industry: A case study of the S\&P 500 index funds, Quarterly Journal of Economics 119, 403-456. 
Hurd, Michael, and Susann Rohwedder, 2012, Stock price expectations and stock trading, NBER Working paper 17973.

Inderst, Roman, and Marco Ottaviani, 2009, Misselling through agents, American Economic Review 99, 883-908.

Inderst, Roman, and Marco Ottaviani, 2012a, Competition through commissions and kickbacks, American Economic Review 102, 780-809.

Inderst, Roman, and Marco Ottaviani, 2012b, Financial advice, Journal of Economic Literature 50, 494-512.

Jensen, Michael, 1968, The performance of mutual funds in the period 1945-1964, Journal of Finance 23, 389-416.

Kaniel, Ron, and Péter Kondor, 2013, The delegated Lucas tree, Review of Financial Studies 26, 929-984.

Knack, Stephen, and Philip Keefer, 1997, Does social capital have an economic payoff? A crosscountry investigation, Quarterly Journal of Economics 112, 1251-1288.

Lakonishok, Josef, Andrei Shleifer, and Robert Vishny, 1992, The structure and performance of the money management industry, Brookings Papers on Economics Activity 1992, 339-391.

Lakonishok, Josef, Andrei Shleifer, and Robert Vishny, 1994, Contrarian investment, extrapolation, and risk, Journal of Finance 49, 1541-1578.

La Porta, Rafael, Florencio Lopez-de-Silanes, Andrei Shleifer, and Robert Vishny, 1997, Trust in large organizations, American Economic Review 87, 333-338.

Malkiel, Burton, 1995, Returns from investing in equity mutual funds 1971 to 1991, Journal of Finance 50, 549-572.

Massa, Massimo, 2003, How do family strategies affect fund performance? When performancemaximization is not the only game in town, Journal of Financial Economics 67, 249-304.

Morris, Stephen, 2001, Political correctness, Journal of Political Economy 109, 231-265. 
Mullainathan, Sendhil, Markus Noeth, and Antoinette Schoar, 2012, The market for financial advice: An audit study, NBER Working paper 17929.

Mullainathan, Sendhil, Joshua Schwartzstein, and Andrei Shleifer, 2008, Coarse thinking and persuasion, Quarterly Journal of Economics 123, 577-620.

Mullainathan, Sendhil, and Andrei Shleifer, 2005, The market for news, American Economic Review 95, 1031-1053.

Philippon, Thomas, 2012, Has the U.S. finance industry become less efficient? On the theory and measurement of financial intermediation, Working paper, New York University.

Prendergast, Canice, 1993, A theory of “yes men," American Economic Review 83, 757-770.

Putnam, Robert, 1993, Making Democracy Work (Princeton University Press, Princeton, NJ).

Scharfstein, David, and Jeremy Stein, 1990, Herd behavior and investment, American Economic Review 80, 465-479.

Shleifer, Andrei, and Robert Vishny, 1997, The limits of arbitrage, Journal of Finance 52, 35-55. 
${ }^{1}$ Berk and Green (2004) argue that low net-of-fee alphas result from competition among investors for access to more skilled managers, who charge higher fees. This theory is challenging to reconcile with negative average after-fee performance, with large fees many investors pay to brokers and advisors who help choose funds, and with the evidently negative relationship between fees and gross-of-fee performance (e.g., Gil-Bazo and RuizVerdú (2009)).

${ }^{2}$ Monopoly power in undifferentiated goods is also present in the models of Carlin (2009) and Gabaix and Laibson (2006). In these models, firms create irrelevant complexity to obfuscate the homogeneity of their goods, and thus to extract surplus from less informed consumers.

${ }^{3}$ A similar assumption is made in the models of Basak and Cuoco (1998) and Cuoco and Kaniel (2011).

${ }^{4}$ Because investors end up hiring their most trusted managers, one should view parameter $a$ as capturing the overall trust that investors have in managers. In turn, $\theta$ captures the dispersion of trust across the two managers. A higher $\theta$ increases both the average mistrust in the less trusted manager and the heterogeneity across investors in the substitutability between the two managers.

${ }^{5}$ The Internet Appendix is available in the online version of the article on the Journal of Finance website.

${ }^{6}$ This fee structure is consistent with widespread market practice. Performance fees would not be useful in this model when investors hold rational expectations, because there are no agency conflicts between investors and managers. Performance fees may be useful when 
investors hold biased expectations of returns. Even in that case, which we study in Section IV, we keep the fee structure unchanged to focus on a nonprice market mechanism, namely, the manager's reputational concern.

${ }^{7}$ Potentially, assets under management may be higher than the initial wealth of investors. This occurs when the expected excess return $R$ is so high that investors wish to lever up by setting $x_{i, j}^{*}>1$.

${ }^{8}$ Inderst and Ottaviani (2009) obtain a similar result in a very different model, where employees of financial intermediaries sell inappropriate products because they are given distorted incentives by their firms.

${ }^{9}$ Dasgupta and Prat (2006) show that career concerns may sometimes induce portfolio managers to trade excessively, contrary to the interests of their clients. Our model alternatively stresses the conventional, positive, view of career concerns. See also Dasgupta, Prat, and Verardo (2011a, 2011b).

${ }^{10}$ Here we simplify the analysis by assuming that investors do not update their beliefs about assets 1 and 2. Formally, the investor has a concentrated prior on asset returns. We could allow the investor to update on both managerial ability and excess return, but this would greatly complicate the analysis.

${ }^{11}$ Again, this logic goes through under the alternative assumption that upon observing an unexpectedly high return investors upgrade their beliefs about both managerial ability and the return of the asset in which the manager's portfolio is intensive. In this case, the algebra is substantially more complex. The real restriction in our analysis concerns the naivete of investors, who are assumed not to infer anything about asset quality when seeing the manager's portfolio choices at $t=0$. 
${ }^{11}$ The same qualitative conditions guarantee the existence of double-pandering equilibria in a linearized version of the model for the general case in which $\theta \leq 1$. (In this linearization, a manager's $t=0$ and $t=1$ profits are linearized around the state in which the two managers have the same returns and assessed abilities.) 